\title{
PLANNING NURSING CARE IN ONCOLOGY: STUDY OF THE STRUCTURE OF SOCIAL REPRESENTATIONS OF NURSES
}

\author{
Rita de Cássia Velozo da SILVA ${ }^{a}$, Enêde Andrade da CRUZ
}

\section{ABSTRACT}

Characterize the social representations of nurses regarding the planning of nursing care for people with cancer, by determining the central nucleus and of the peripheral system. Qualitative study conducted in a specialized hospital in Salvador, Bahia, between July 2008 and March 2009. Data collection was made by free association of words, with forty-one nurses. The data were processed by the software Ensemble de Programmes Permettant L'analyse des Evocations and analyzed according to the Theory of Social Representations. The results indicated the following central elements: humanization, care, organization, individualizing and suffering. In the peripheral system, professional and personal attitudinal elements necessary for the planning were observed: skill, knowledge on the disease, family care, respect and sensitivity. It is concluded that care planning is linked to the peculiarities of the individual with cancer, and requires that nurses have knowledge and skills necessary to prioritize actions and ensure the quality of care.

Descriptors: Oncology nursing. Patient care planning. Social psychology.

\section{RESUMO}

Analisar as representações sociais de enfermeiras acerca do planejamento da assistência de enfermagem à pessoa com câncer, mediante a determinação do núcleo central e do sistema periférico. Estudo qualitativo realizado em um hospital especializado, em Salvador, Bahia, entre julho de 2008 e março de 2009. A coleta de dados foi efetivada pela associação livre de palavras, com 41 enfermeiras. Os dados foram processados pelo software Ensemble de Programmes Permettant L'analyse des Evocations e analisados segundo a Teoria das Representações Sociais. Os resultados indicaram como elementos centrais: humanização, cuidado, organização, individualizar $e$ sofrimento. No sistema periférico, apareceram elementos atitudinais profissionais e pessoais necessários ao planejamento: habilidade, conhecimento sobre a doença, cuidar da família, respeito e sensibilidade. Conclui-se que o planejamento assistencial está vinculado às peculiaridades da pessoa com câncer, e requer conhecimento e habilidades da enfermeira de modo a priorizar ações e buscar qualidade da assistência.

Descritores: Enfermagem oncológica. Planejamento de assistência ao paciente. Psicologia social.

Título: Planejamento da assistência de enfermagem em oncologia: estudo da estrutura das representações sociais de enfermeiras.

\section{RESUMEN}

Analizar las representaciones sociales de las enfermeras sobre la planificación de los cuidados de enfermería a la persona con cáncer, mediante la identificación del núcleo central y sistema periférico. Estudio exploratorio y descriptivo, realizado en un hospital especializado en Salvador, Bahia, entre julio de 2008 y marzo de 2009. La recolección de datos fue realizada por la asociación libre de palabras con cuarenta y una enfermeras. Los datos fueron procesados por el software Ensemble de Programmes Permettant L'analyse dês Evocations y analizados basados en la Teoría de las Representaciones Sociales. Los resultados indicaron elementos centrales: el cuidado humano, la organización, individualizar y el sufrimiento. En el sistema periférico, elementos de las actitudes personales y profesionales necesarias para planificar. Se concluye que la planificación de la atención está relacionada con las peculiaridades de la persona con cáncer, y requiere conocimientos y habilidades de la enfermera para priorizar las acciones y buscar la calidad de la atención.

Descriptores: Enfermería oncológica. Planificación de atención al paciente. Psicología social.

Título: Planificación de los cuidados de enfermería en oncología: estudio de la estructura de las representaciones sociales de enfermeras.

\footnotetext{
a Master in Nursing, PhD student in the Postgraduate Program in Nursing of Universidade Federal da Bahia (UFBA), Professor at Faculdade Ruy Barbosa, participates in the Study Group on Women's Health, Salvador, Bahia, Brazil. E-mail: rvelozo2009@gmail.com.

b PhD in Nursing, Professor at the Postgraduate Program in Nursing of UFBA, Salvador, Bahia, Brazil. E-mail: enedeeac@ig.com.br.
} 


\section{INTRODUCTION}

Nurses plan care as a way to organize, prioritize and systematize their activities, combining direct assistance with care management, considering the needs of patients. In oncology, several peculiarities permeate the daily lives of these professionals: the stigma still attached to the condition; the relationship with the patient/family; care in invasive and/or painful procedures; situations of severity and death, demonstrating the complexity of attention to this type of patient.

The management of care is part of the work of nursing professionals, with focus on the patient's needs and service integration, to provide a comprehensive health care $^{(1)}$. Planning is the first step of any nursing care activity. It involves setting the goals of care, analyzing the consequences that might arise from different situations, set specific goals to achieved and develop strategies for the implementation of appropriate therapy ${ }^{(2)}$.

In this social context of belongingness to a group (e.g. family, a company (workplace), this activity is conceived by the individual or the group as an extension of their behavior, attitudes, rules, beliefs and values, where social representations can emerge $e^{(3)}$.

The concept of social representation adopted here concerns "[ [...] a set of concepts, propositions and explanations originating in the daily life, during interpersonal communications, which is a sort of commonsense theory" ${ }^{\left({ }^{(}\right)}$. In the approximation of the Theory of Social Representations (TSR) and the health care field, it is necessary to establish new foundations for the care process in health based on the "represented needs", negotiated between individual and collective subjects and the professionals of health care institutions, and accessed through social representations ${ }^{(5)}$.

The TSR recognizes the value of the subjective dimension, the cognitive aspect of the individual that interferes in social practices, attitudes and behaviors related to the object of representation. The use of this theory allows us to clarify the process of assimilation of facts in the social context, how they are understood by individuals and groups, and how knowledge built on these facts is expressed in their communication and behaviors ${ }^{(6)}$.
According to the structural approach to social representations ${ }^{(3)}$ every representation is organized around a central nucleus $(\mathrm{CN})$ that determines, at the same time, its significance and internal organization; and by a peripheral system with flexible elements that allow a greater interaction with the context, giving accessibility to reality, ensuring, regulating, advocating and giving stability to the $\mathrm{CN}$. These elements are the operational part of the representation the interface between concrete reality and the central nucleus.

The Social Representations (SR) have a practical function, and the central nucleus has two main functions: generating function - it is the element through which the meaning of the other components of the representation is created or transformed. The other elements gain a sense, a value through the central nucleus. The other function is the organizing function, where the $\mathrm{CN}$ determines the nature of the links, uniting the elements of the representation. In this perspective, the nucleus is the element that unites and stabilizes the representation ${ }^{(4)}$.

The identification of the $\mathrm{CN}$ and the peripheral elements of SR on the planning of nursing care, object of this study, can reveal what is actually being represented by the group to which they belong, since the activities performed by nurses in this field may reflect their views on the experiences and changes of their daily practice.

Therefore, the planning activity depends on the individual condition of those who perform it, and may be influenced by internal and external situations inherent to the relationships established in the group ${ }^{(5)}$, including the emotions of nurses in their interaction with the patient with cancer, family members and others present at the time of planning. Our considerations are consistent with Pearce ${ }^{(7)}$ and Maturana ${ }^{(8)}$, when they emphasize that emotion determines the attitude adopted and experienced by the individual in each situation.

In our literature review of the subject we noticed that there is a lack of research into the planning of nursing care that address the representation of this activity for nurses. Thus, the guiding question of this study was: How do nurses socially represent the planning of nursing care for patients with cancer? And aimed to analyze the social representations elaborated by nurses on their 
planning of nursing care for patients with cancer, from the identification of elements of the $\mathrm{CN}$ and the peripheral system.

\section{METHODOLOGY}

Qualitative study with data extracted from the dissertation entitled "Planning of Nursing Care for Cancer Patients: Social Representations of Nurses"(9), and developed with the contribution of the Theory of Social Representations (TSR) ${ }^{(4)}$ from the perspective of the Central Nucleus ${ }^{(3)}$.

After approval by the Research Ethics Committee of the organization, protocol no 213/08, the field research was developed between August/2008 and March/2009, in a large, philanthropic hospital, in Salvador - Bahia, selected because it is specialized in oncology and has a structured and organized 24-hour nursing service.

The inclusion criteria were: being a nurse and who has been working in the hospital for at least one year (time deemed necessary for the construction and stabilization of the SR) and in the three work shifts. The exclusion criterion was: being a nurse who does not perform healthcare tasks.

The Free Word Association Test (FAT) was used for data collection, considering the quantitative and qualitative properties in determining the social representation, through the central nucleus and the peripheral system ${ }^{(10)}$.

For the FAT, the participants were asked to answer the following inducing question: "Say five words that come to mind when the topic is the planning of nursing care for cancer patients", and indicate the one considered most important. There was no understanding bias regarding the inducing question.

The FAT is a projective test of Psychology that allows restraining the difficulties and limits of discursive expressions, helping to locate areas of blocks and repressions of an individual, that is, deleting the field of consciousness of certain ideas, feelings and desires that the individual does not want to admit, and that are often difficult to express or are camouflaged in the speech. ${ }^{(11)}$.

The ethical issues governing research with humans were respected, according to the current resolution $^{(12)}$. The participants were previously informed on the importance of the study, on consent for the recording of the interview and on the signing of the Free Informed Consent Form. The product obtained with the free word association test was processed and analyzed by the software Ensemble de Programmes Permettant L'analyse des Evocations (EVOC) $)^{(13)}$.

\section{RESULTS AND DISCUSSION}

The sample consisted of 41 professionals who met the established criteria, totaling $75.92 \%$ of the eligible subjects for the study. The age of the interviewees ranged from 21 to 51 years, with an average of 33 years. There were 40 female nurses and one male nurse. The working time in the hospital ranged from 1 to 25 years, most of them have been working there for 1 to 5 years.

The participants were interviewed individually and evoked 202 words, and nine words referred only once were eliminated, according to the methodological guidelines to provide more consistency and clarity to the representation ${ }^{(14)}$. The remaining words totaled 193, and accounted for $95.54 \%$ of the total, constituting the corpus of the research with 27 different words.

The data showed an average order of evocations of around three and the average frequency was around seven. These data allowed the construction of vertical and horizontal lines that divide the table of four quadrants, where the vertical axis corresponds to the average frequency, and the horizontal axis to the average order of evocation.

Table 1, elaborated by software EVOC, shows the possible elements of the central system and the peripheral system of representation of this activity, according to the views of the respondents.

In this set of quadrants, each one incorporates elements construed as follows: the most significant and readily evoked words are located in the first quadrant (upper left). These are words that can be part of the $\mathrm{CN}$, with greater frequency of evocation and lower average order of evocation. They can reveal the latent, spontaneous speeches of the research subjects, because the act of evoking brings to mind spontaneously and readily something that is in the memory of individuals, which is equivalent to the norms, values, ideas and beliefs ${ }^{(15)}$.

The elements of the second quadrant (upper right) are considered of 1 st periphery, and can be moved to the 1st quadrant of the $\mathrm{CN}$ or the 4th 


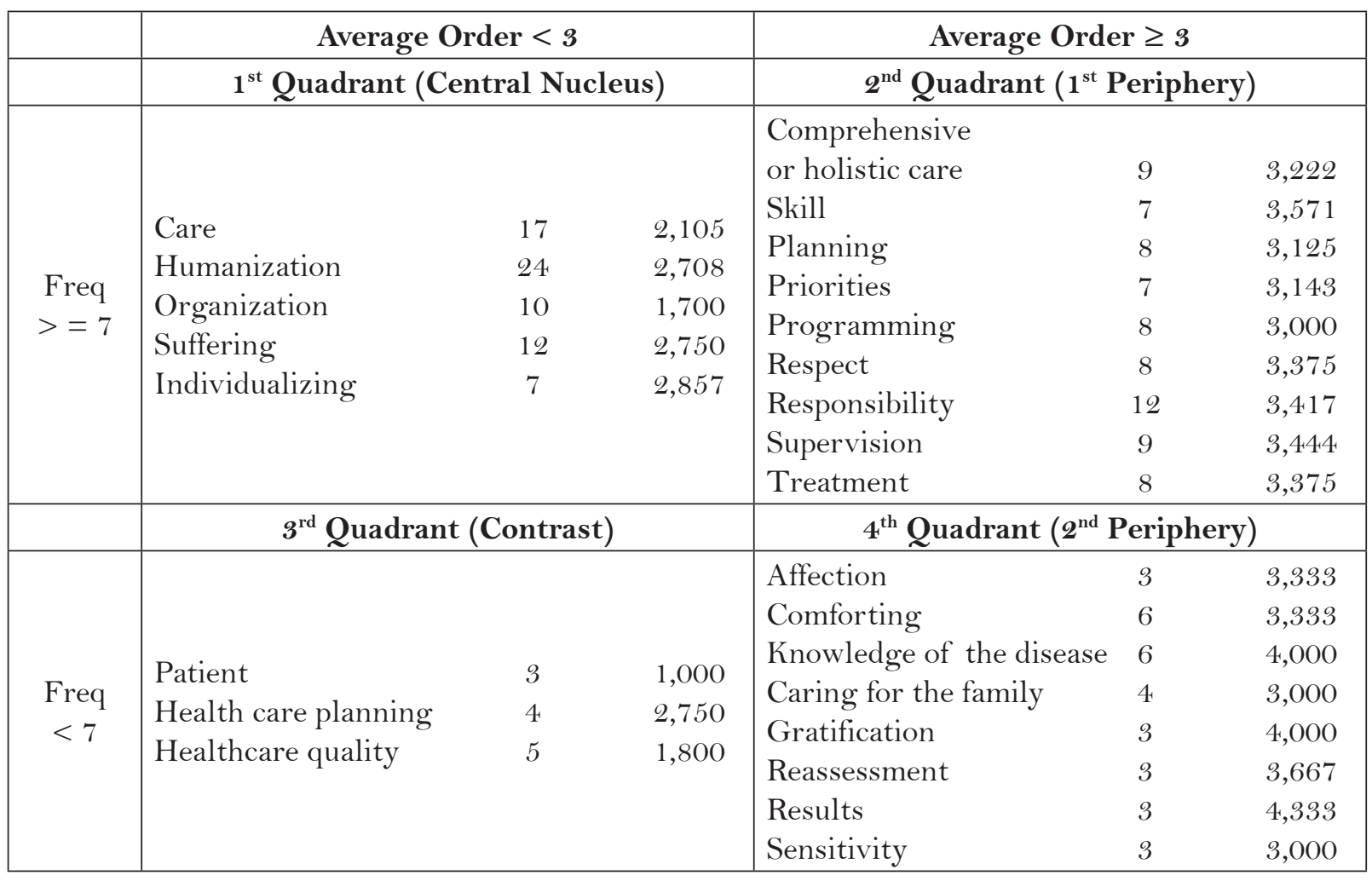

Table 1 - Viewing of the Central Nucleus. Planning of Nursing Care to Cancer Patients: frequency and average order of the words evoked. N. 41 - Salvador - Bahia, 2009.

Source: Research data.

right lower quadrant, or else, the peripheral system. These elements have the lowest frequency of evocation, have the highest average order of evocation, that is, the individuals can intentionally elaborate the element before expressing it. ${ }^{(4,11)}$. The elements of the third quadrant (lower left) are contrasting and can be analyzed by the $\operatorname{TSR}^{(4)}$.

The upper left quadrant $(\mathrm{CN})$ contains the elements humanization, care, suffering, organization and individualizing, and may represent essential elements in determining the professional attitude of nurses regarding care planning for cancer patients. They concern the attitudes and behaviors associated to what "must be done"(10), directly related to the organizational norms. The peripheral system, in turn, highlights those behaviors that "need to be used", which are triggered when necessary, as more concrete and accessible components for the support and maintenance of the functions of the $\mathrm{NC}^{(3)}$.

The elements of the peripheral system promote the interface between the concrete reality experienced by the nurses and the centrality of representation on the planning of nursing care, regarding the daily experiences that generate more individualized representations. These elements relate to professional and personal qualities necessary for the planning of nursing care, such as knowledge on the disease, reassessment, sensitivity. Somehow, these peripheral elements are basic and organized into complex structures that permeate the entire representation $^{(16)}$.

The elements of the $\mathrm{CN}$ and the peripheral system showed significant meanings of the representation of nursing care planning by the nurses, characterizing the common sense of this group, and expressing the inner nature of issues inherent to the development of the nursing profession within the context of an oncologic hospital. The daily activities performed by nurses may reflect their views on their experiences and changes of their practice, which support the elements of the $\mathrm{CN}$.

Based on the various concepts that have been raised and hierarchized according to their place in the structure of the representation, the cores that 
constituted two central categories and two peripheral categories were identified, as follows:

\section{Central categories}

The first central category - Planning of Nursing Care to Cancer Patients and Humanization - determined by the expressions: care, suffering, comforting and caring for the family, denote the complexity of the care planning activity by oncologist nurses. This category is one of the main cores of the SR structure on nursing care planning and is linked to the concern of respondents with the care provided to cancer patients.

Regarding the demands for nursing care, for an appropriate nursing care planning the nurses and their staff need to understand the impact of cancer and its treatment on the individual's life. Based on this understanding, the professionals can adjust their actions to the available resources for health care, giving a more humanistic and qualified character to this care. This implies also perceiving the individuals with their weaknesses and needs, and help them face these difficult times, through a more humanized care ${ }^{(17)}$.

In nursing care planning for cancer patients, the suffering may be related to the patient in the fear of the unknown, in the pain caused by the treatment, in the possible mutilations and deformities caused by the disease, in the impaired self-image, in the low self-esteem, in the distance from family, or related to the professionals, in the need to perform care activities/procedures that promote discomfort and/or cause pain, besides witnessing the distress of these individuals and their families.

This reality, very common in the health care area, causes professionals to show compassion and sympathy towards cancer patients and their families during the disease ${ }^{(18)}$, and because they are aware of the difficulties faced by patients and their family members in the public healthcare system. Also, nurses may sometimes experience a feeling of helplessness when they have to deal with patients at advanced stages of the disease.

The hospital where this study was conducted, with around 200 beds, cannot always meet the regular demands, nor take referrals from other cities of Bahia and other states, and the professionals witness the daily reality of patients having to cope with delay in diagnosis, delayed prescription of treatment and/or unmet needs.

The presence of a serious illness generates feelings and reactions that need to be understood by nursing professionals, since the disease has a great impact on patients, and these rely heavily on family ties. Nurses can help the sick individuals and their families by increasing their ability to cope with the illness, treatment and risk situations, through a nursing care planning consistent with their needs and possibilities.

The second central category - Planning of Nursing Care for Cancer Patients and Organization - is formed by the evocations individualizing, planning, comprehensive care and supervision. This category appears to be focused on the instrumentalization of knowledge as a reference object for its practice, on the construction of social relations and the development of planning itself.

Comprehensive care is inserted here to demonstrate the importance of the care provided by nurses and their teams, from the beginning of treatment to palliative care. It is worth stressing that nursing care planning is a tool that guides professional caregivers, and nurses' action go beyond the planning and execution of techniques.

Currently, the care methods used by nurses represent an important achievement in their assistance practice, providing opportunities for the nursing staff to share expectations and experiences, to feel more valued and jointly responsible for the practices of continuous improvement of $\operatorname{care}^{(2)}$.

Also, an organizational structure that provides the necessary conditions for the implementation of this highly qualified and special nursing care for cancer patients is required.

The fulfillment of the demand of these people, however, can only occur through a variety of actions planned and implemented by a health care network that ensures individualized care. Therefore, when organizing such care, nurses should consider the identified nursing diagnoses, so that interventions can provide comprehensive care to patients.

Such interventions need to be monitored by nurses and also supervised, since many health care activities are performed by other professionals of the nursing staff. This is corroborated by other authors $^{(19)}$, who they affirm that supervision, as a management tool, should be used by nurses as a device that allows the emancipation and develop- 
ment of citizenship by the agents involved in the work process, for it allows the implementation of a care plan and ongoing assessment of such care.

\section{Peripheral categories}

The first peripheral category - Planning of Nursing Care to Cancer Patients Associated with Professional Qualities - highlights the essential qualities for the planning of nursing care: responsibility, skill, knowledge on the disease and reassessment.

The nurses who have these qualities are able to meet the patients' needs, use their knowledge on cancer to improve their practice, consider the family members as a unit of care and are always focused on it, which requires continuous assessment of the results of nursing interventions.

So, the responsibility of nurses may concern the lives of patients with cancer under their care and the need to perform the procedures safely. It can also be associated to the system of standards and values of this group, which corresponds to their guidelines for planning nursing care, by relating aspects such as the comprehensiveness of care.

It may also involve the knowledge and professional experience of nurses combined with their personal characteristics that enable them to provide care to cancer patients.

Thus, nurses need to continuously broaden and deepen their specific knowledge, considering the multidimensional and/or multidisciplinary approach inherent to their practice ${ }^{(2)}$.

The evocations demonstrated the importance attached by nurses to elements relevant to the planning of nursing care, recognizing this activity as a factor that can contribute to the quality of care in oncology, and at the same time, express one need perceived by them, that such planning requires abilities, knowledge from the individual who plans and performs this planning, besides suitable organizational conditions to ensure that humanized care is provided.

The prescription of care must be consistent with the planning of nursing care, have scientific basis, be individualized, provide a safe and therapeutic environment, promote learning opportunities for the individual, and be consistent with the resources available in the unit.

The second peripheral category - Planning of Nursing Care to Cancer Patients associated to
Personal Qualities - is related to personal qualities nurses should have to provide care to cancer patients, such as respect, affection, sensitivity and gratification.

Regarding common sense, these elements emphasize the importance of adding humanistic values to the nursing practice, which will make it easier for the professionals to cope with difficult situations of their everyday work and provide a comprehensive and high-quality care to their patients. Considering the psychosocial aspects of planning implies understanding them as something developed by human beings and targeted to other human beings, which involves the feelings and expectations of both subjects, at a particular place and time, with their values, beliefs and views.

This behavior can be directly associated to the history or collective memory of this group, their system of norms and values and the nature of their involvement in the social situation experienced ${ }^{(3)}$. which concerns the guidelines the govern the nursing practice by establishing the qualities that nurses should have to provide adequate nursing care to cancer patients, and satisfactorily interact with the nursing staff and the patients' family members.

Therefore, it is essential that nurses participate in discussions and strategic negotiations that ensure proper health and add different technologies to their actions, considering the subjective and sensitive content that permeates health care. The non-routine, personal character in the relationships between the subjects that participate in the work processes need to be recognized, so that the individual objectives - of users and workers - and of the organization itself - are achieved. ${ }^{(20)}$.

\section{FINAL CONSIDERATIONS}

The analysis of evocations obtained with the free word association test led to the characterization of the components of the structure of the SR of nurses regarding the planning of nursing care to cancer patients. Using the contributions of the TSR it was possible to identify the existence of a process of relationship and interaction between the nurse and the planning practice, which makes it possible for the professional to make decisions based on the representational elements. 
A representation of the meaning of planning was found to be linked to humanization and organization of care, as well as to important affective and attitudinal values associated with the delivery of patient-centered care. The nurses were committed to the development of a special care planning, but also aware of the existence of limiting factors (including those related to the patient, advanced stage disease, the organization (hospital/centre), among others that often undermine its implementation.

It is expected that this study contributes to the reflection of nurses and their staff on the complexity of the care administered to cancer patients, as well as to raise awareness among managers of the need to value the work of the team of oncology nursing.

The findings of this study do not allow generalizations, since they are restricted to one hospital unit, and point to the need for more in-depth studies on the social representations of oncology nurses, in view of the complex and dynamic nature of their practice.

\section{REFERENCES}

1 Hausmann M, Peduzzi M. Articulação entre as dimensões gerencial e assistencial do processo de trabalho do enfermeiro. Texto Contexto Enferm. 2009;18(2):258-65.

2 Fugita RMI, Farah OGD. O planejamento como instrumento básico do enfermeiro. In: Cianciarullo TI, organizador. Instrumentos básicos para o cuidar: um desafio para a qualidade da assistência. São Paulo: Atheneu; 1996.

3 Abric JC. Abordagem estrutural das representações sociais: desenvolvimentos recentes. In: Campos PH, Loureiro MCS, organizadores. Representações sociais e práticas educativas. Goiânia: UCG; 2003. p. 37-57. Série Didática, 8.

4 Moscovici S. A representação social da psicanálise. Cabral A, tradutor. Rio de Janeiro: Zahar; 1978.

5 Oliveira DC. A teoria de representações sociais como grade de leitura da saúde e da doença: a constituição de um campo interdisciplinar. In: Almeida AMO, Santos MFS, Trindade ZA, organizadores. Teoria das representações sociais. Brasília: Technopolitik; 2011. p. 585-623.
6 Silva SED, Camargo BV, Padilha MI. A Teoria das Representações Sociais nas pesquisas da Enfermagem Brasileira. Rev Bras Enferm. 2011 set-out;64(5):947-51.

7 Pearce, WB. Novos modelos e metáforas comunicacionais: A passagem da teoria à prática, do objetivismo ao construcionismo social e da representação à reflexividade. In: Schnitman, DF. Novos paradigmas de cultura e subjetividade. Porto Alegre: Artes Médicas; 1996. Cap. 9, p. 171-87.

8 Maturana H. Ciência e vida cotidiana: a ontologia das explicações científicas. In: Magro C, Paredes V, organizadores. Cognição, ciência e vida cotidiana. Belo Horizonte: UFMG; 2001.

9 Silva RCV, Cruz EA. Planejamento da assistência de enfermagem ao paciente com câncer: representações sociais de enfermeiras [dissertação]. Salvador (BA): Programa de Pós-Graduação em Enfermagem, Universidade Federal da Bahia; 2009.

10 Sá CP. Núcleo central das representações sociais. Petrópolis: Vozes; 2002.

11 Oliveira DC, Marques SC, Gomes AMT, Teixeira MCTV. Análise das evocações livres: uma técnica de análise estrutural das representações sociais. In: Moreira ASP, organizador. Perspectivas teórico-metodológicas em representações sociais e práticas educativas. João Pessoa (PB): UFPB; 2005. p. 573603.

12 Ministério da Saúde (BR). Resolução Nº 196/96 sobre pesquisa envolvendo seres humanos. Bioética. 1996;4(2 Supl):15-25.

13 Vergés P. L'evocation de l'argent: une méthode pour la définition de noyau central d'une représentation. Bulletin de Psychologie. 1992;xlv(405):203-9.

14 Tura LFR. Os jovens e a prevenção da Aids no Rio de Janeiro [tese]. Rio de Janeiro (RJ): Universidade Federal do Rio de Janeiro; 1997.

15 Silva IAS, Cruz EA. Trabalho da enfermeira intensivista: um estudo da estrutura da representação social. Rev Esc Enferm USP. 2008;42(3):554-62.

16 Campos HF. A abordagem estrutural e o estudo das relações entre práticas e representações sociais. In: Campos PHF, Loureiro MCS, organizadores. Representações sociais e práticas educativas. Goiânia: UCG; 2003. p. 21-36. 
17 Molina MAS, Gonzaga MTC, Oliveira, MLF. Cuidado e enfermagem: reflexões sobre essa parceria. Arq Apadec. 2004;8(Supl):284-91.

18 Teixeira FB, Gorini MIPC. Compreendendo as emoções dos enfermeiros frente aos pacientes com câncer. Rev Gaúcha Enferm. 2008;29(3):367-73.
19 Santos JLG, Lima MADS. Gerenciamento do cuidado: ações de enfermeiros em um serviço hospitalar de emergência. Rev Gaúcha Enferm. 2011;32(4):695-702.

20 Rossi FR, Silva MAD. Fundamentos para processos gerenciais na prática do cuidado. Rev Esc Enferm USP. 2005;39(4):460-8.

\author{
Author's address / Endereço do autor / \\ Dirección del autor \\ Rita de Cássia Velozo da Silva \\ Rua Professor Jairo Simões, 181, ap. 202, Imbuí \\ 41720-375, Salvador, BA \\ E-mail: rvelozo2009@gmail.com
}

Received: 24.07.2013

Approved: 11.02.2014 